It also shows that pinguinain is a protein having a small molecular weight.

Radioisotope Service,

Veterans Administration Hospital,

San Juan, Puerto Rico;

and University of Puerto Rico

School of Medicine,

San Juan, Puerto Rico.

'Porath, J., and Flodin, P., Nature, 183, 1657 (1959).

${ }^{2}$ Hjertén, S., and Mosbach, R., Anal. Biochem., 3, 109 (1962).

"Steere, R. L., and Ackers, G. K., Nature, 196, 475 (1962).

- Pederson, F. O., Arch. Biochem. Biophys., Supp., 1, 157 (1962).

- Ackers, G. K., Biochem. (in the press).

-Messing, R. A., Santoro, A. F., and Block, A., Enzymologia, 22, 110 (1960)。

'Messing, R. A., Enzymologia, 22, 117 (1960).

- Toro-Goyeo, E., Matos, M., and Cancio, M., Fed. Proc., 22, 528 (1963).

- Svedberg, 'T., and Pedersen, K. O., The Ultracentrifuge (Clarendon Press, Oxford, 1940 ).

\section{Inhibitory Effect of Progesterone on Activity of Human Myometrial Adenosine Triphosphatase}

DURING the previous investigations ${ }^{1}$ in this laboratory human myometrial strips were exposed to progesterone until all spontaneous activity ceased and the changes in the concentration of adenosine triphosphate (ATP) and phos. phocreatine (PC) measured. Until such paralysis had existed for at least $40 \mathrm{~min}$, no significant change in highenergy phosphate bonds (ATP and PC) could be documented. It was, therefore, concluded that in the earlier stages of the myometrial inhibition progesterone might be exerting its effect in the utilization of ATP rather than in its synthesis. As a continuation of the investigations on this problem, the effect of progesterone was then determined on the ATPase activity of the human myometrial strips. This communication deals with the results obtained.

The method of DuBois and Potter ${ }^{2}$ was used to determine the ATPase activity in which human non-pregnant myometrial tissue homogenate was incubated in the presence of calcium chloride, diethyl barbiturate (buffer) and ATP. The amount of inorganic phosphorus liberated in homogenate corresponding to $6 \mathrm{mg}$ and $9 \mathrm{mg}$ wet weight tissue in $15 \mathrm{~min}$ at $37^{\circ} \mathrm{C}$ as determined by the procedure of Rockstein and Herron ${ }^{3}$ was taken as a measure of ATPase activity. One microgram of phosphorus liberated was interpreted as one unit of ATPase activity. Ten to $300 \mu \mathrm{g}$ of progesterone dissolved in $30 \lambda$ of propylene glycol was added to the homogenate to determine its effect.

The two requirements: $(a)$ that the rate of reaction is linear during the time of incubation; $(b)$ that the rate is directly proportional to the amount of enzyme present in the test system, should be fulfilled if any enzyme assay is to be found satisfactory.

Propylene glycol used as a vehicle $(30 \lambda)$ did not alter the ATPase activity. Progesterone in concentrations of more than $10 \mu \mathrm{g}$ (and up to $50 \gamma$ tested) per mg wet weight human myometrial tissue was found to inhibit the human myometrial ATPase activity on an average of $27 \cdot 3$ per cent $(P<0.001)$ based on 15 experiments as shown in Table 1.

It is interesting to note that such high concentrations of progesterone were needed to inhibit the human myometrial ATPase activity. It may be that the smaller concentrations of progesterone might inhibit the ATPase

Table 1

$\begin{array}{ccc}\begin{array}{c}\text { No. of } \\ \text { cases }\end{array} & \begin{array}{c}\text { Average ATPase activity in units of human } \\ \text { myometrial tissue/mg wet weight }\end{array} \\ \begin{array}{cc}\text { Control Progesterone treated }(90-300 \mu \mathrm{g}) \\ 15\end{array} & \begin{array}{c}\text { Average reduction } \\ \text { in ATPase activity } \\ \text { by progesterone }\end{array} \\ & \begin{array}{l}1.98 \\ +1 \text { ATPase unit }=1 \mu \mathrm{g} \text { phosphorus liberated. } \\ +\ell=7.09 .\end{array} \\ & P<0.001 .\end{array}$

activity when exposed to spontaneously contracting myometrial strip in muscle-bath preparation over a prolonged period of time. Such an investigation is in progress and the results will be reported later.

This work was supported by grant $H D-00523-04$, U.S. Public Health Service.

\section{KUMAR \\ P. R. AdaMs \\ A. C. BARNES}

Department of Gynæcology and Obstetrics, Johns Hopkins University

School of Medicine and Hospital, Baltimore.

1 Kumar, D., and Barnes, A. C., Bull. Johns Hopkins Hosp., 113, 330 (1963). - DuBois, K. P., and Potter, V. R., J. Biol. Chem., 150, 185 (1943).

${ }^{3}$ Rockstein, M., and Herron, P. W., Anal. Chem., 23, 1500 (1951).

\section{Stimulation of Glucose Utilization by Insulin in Human Adipose Tissue Homogenates}

To date no effect of insulin on utilization of glucose in a cell-free preparation has been described. Indeed, the apparent inoffectiveness of insulin in cell-free preparations was a major clue to the discovery of the insulin stimulation of trans-membrane transport. We have been examining utilization of glucose in human adipose tissue and have observed a distinct stimulation of utilization of glucose by insulin added to homogenates of omentum.

Omentum was obtained from subjects undergoing abdominal surgery being performed for reasons other than malignancy. Homogenization was achieved within 15 sec, using a 'Vir 'Tis 23' homogenizer in a Krebs-Ringer bicarbonate buffer ${ }^{2}$ gassed with $\mathrm{O}_{2}: \mathrm{CO}_{2}(95: 5)$ to $p \mathrm{H} 7 \cdot 4$. The potassium chloride concentration of the buffer was doubled at the expense of the sodium chloride. A 'defatted' homogenate was obtained by removing the supernatant layer of congealed fat formed during centrifugation in the cold at $500 \mathrm{~g}$ for $10 \mathrm{~min}$. The homogenate was then supplemented to give final concentrations of $0.001 \mathrm{M}$ ATP, $0.001 \mathrm{M} \mathrm{TPN}^{+}, 0.005 \mathrm{M} \mathrm{Mg}^{++}$and $5.6 \mathrm{mM}$ glucose. Incubation vessels containing $1 \mathrm{ml}$. of homogenate were incubated for $\mathrm{l} \mathrm{h}$ at $37^{\circ} \mathrm{C}$ with agitation at $60 \mathrm{cycles} / \mathrm{min}$. Insulin was added to give a concentration of 0.1 unit $/ \mathrm{ml}$. homogenate. Glucose was measured by a micro adeptation of the glucose oxidase method of Sunderman and Sunderman ${ }^{2}$.

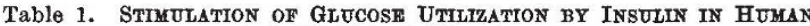
\begin{tabular}{cccc}
\multicolumn{4}{c}{ ADIPOSE TISSOE HOMOGENATES } \\
Glucose utilization & Without insulin & With insulin & $\Delta$ Insulin \\
$\mu \mathrm{g} / \mathrm{mg}$ tissue $\mathrm{N}_{\mathrm{g}} / \mathrm{h}$ & $279 \pm 75$ & $466 \pm 246$ & $187 \pm 105 *$ \\
Values are means $\pm S, D$, in 11 experiments & \\
$* P<0.01$. &
\end{tabular}

As seon in Table 1 , insulin produced a 67 per cent increase in glucose disappearance. Though there is indirect evidence of an intracellular action of insulin on both carbohydrate ${ }^{3}$ and protein metabolism ${ }^{4}$, we believe that this is a direct demonstration of an intracellular insulin effect on utilization of glucose. Previous inability to show such an effect may have been due to the choice of tissue and incubation conditions.

This work was supported by a grant from the Medical Research Council of Canada.

\section{A. KAHLENBERG \\ N. KaLANT}

Research Laboratory, Jewish General Hospital,

and Department of Investigative Medicine,

McGill University, Montreal, Canada.

${ }^{1}$ Umbreit, W. W. Burris, R. H., and Stauffer, J. R., in Manometric Tech-

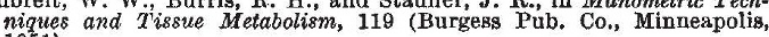
1951).

'Sunderman, jun., W., and Sunderman, F. W., Amer, J. Clin. Path., 36. 75 (1961).

${ }^{3}$ Leonards, J. R. Landau, B. R., and Bartsch, G., J. Lab. Clin. Med., 60, 552 (1962).

' Korner, A., and Manchester, K. L., Brit. Med. Bull., 16, 233 (1960). 